\title{
Potamogeton xjacobsii (Potamogetonaceae) from New South Wales, Australia - the first Potamogeton hybrid from the Southern Hemisphere
}

\author{
Zdenek Kaplan', Judith Fehrer ${ }^{1}$ and C. Barre Hellquist ${ }^{2}$ \\ ${ }^{1}$ Institute of Botany, Academy of Sciences of the Czech Republic, 25243 Prühonice, Czech Republic \\ Email: kaplan@ibot.cas.cz,fehrer@ibot.cas.cz \\ ${ }^{2}$ Department of Biology, Massachusetts College of Liberal Arts, North Adams, \\ Massachusetts 01247 U.S.A. \\ Email: c.barre.hellquist@mcla.edu
}

\begin{abstract}
Although more than 80 hybrids are documented for Potamogeton in the Northern Hemisphere, the hybrid diversity in the Southern Hemisphere is largely unknown. A taxonomically uncertain Potamogeton plant discovered in New South Wales, Australia, was subjected to detailed morphological investigation and molecular analyses to discover its exact identity. Both approaches resulted in the identification of the Potamogeton specimen as P. crispus $\times$ $P$. ochreatus, which is a previously unrecorded hybrid and is here described as Potamogeton $\times$ jacobsii nothosp. nova. Although $P$. crispus is known to hybridise with many other species, $P$. $\times$ jacobsii is the first known hybrid involving P. ochreatus.
\end{abstract}

\section{Introduction}

The occurrence of hybridisation in pondweeds (Potamogeton and Stuckenia, Potamogetonaceae) has been known for more than a century (see the reviews in Wiegleb et al. 2008 and Kaplan et al. 2009). Besides traditional morphological comparisons, stem anatomy (e.g., Raunkiær 1896, 1903; Fischer 1904, 1905, 1907; Hagström 1916; Ogden 1943; Symoens et al. 1979; Wiegleb 1990a, 1990b; Kaplan 2001, 2005a, 2005b; Kaplan \& Symoens 2004, 2005; Zalewska-Gałosz et al. 2010), isozyme electrophoresis (e.g., Hollingsworth et al. 1995, 1996; Preston et al. 1998; Fant et al. 2001a, 2001b; Iida \& Kadono 2002; Kaplan et al. 2002; Fant \& Preston 2004; Kaplan \& Wolff 2004; Kaplan 2007) and DNA-based techniques (King et al. 2001; Fant et al. 2003; Kaplan \& Fehrer 2004, 2006, 2007, 2009; Ito et al. 2007; Wang et al. 2007; Du et al. 2009; Kaplan et al. 2009; Zalewska-Gałosz et al. 2009, 2010) have all contributed to our understanding of diversity, morphological variation and distribution in Potamogetonaceae hybrids. 
Table 1. Samples used in the molecular analyses.

Taxon Ref. no. Origin and collection records

Czech Republic, Bohemia, Bohuslavice, coll.

Z. Kaplan 03/121 (PRA)

1464 Czech Republic, Bohemia, Velká Jesenice, coll. Z. Kaplan 03/122 (PRA)

1472 Germany, Bavaria, Ebing, coll. L. Meierott, cult. Z. Kaplan 1472 (PRA)

1473 Czech Republic, Bohemia, Poděbrady, coll. AY529524 GU814256 Z. Kaplan 03/142 (PRA)

2022 India, Jammu and Kashmir State, Manasbal Lake, GU814244 coll. A. H. Ganie, cult. Z. Kaplan 2022 (PRA)

ITS GenBank rp/20-5'-rps12

no.

GenBank no.

GU814242 GU814253

GU814243 GU814254

AY529523 GU814255

GU814257

2215 Australia, West Australia, Joondalup Lake, coll. GU814245 HM852142 M. Moody WP271 (PERTH)

P. $\times$ jacobsii 2034

Australia, New South Wales, Narellan, coll.

GU814246-

GU814249

P. ochreatus $1071 \quad$ New Zealand, North Island, Lake MacLaren, coll. GU814250 D. Hofstra, cult. Z. Kaplan 1071 (PRA)

1072 New Zealand, North Island, Lake Rotoaira, coll GU814251 D. Hofstra, cult. Z. Kaplan 1072 (PRA)

GU814252 HM852141

GU814258

GU814259

GU814260 M. Moody WP270 (PERTH)

Table 2. Comparison of the most important diagnostic characters of Potamogeton crispus, P. ochreatus and their hybrid, P. xjacobsii.

Character
Shape of leaves
Length of leaves (mm)
Width of leaves (mm)
Length:width ratio of
leaves
Shape of leaf apex
Shape of leaf margin
Presence and number of
sclerenchymatous strands
in leaves in addition to
vascular veins
Shape of stem in cross-
section

\section{P. crispus}

linear-oblong

25-95

$(4-) 6-12$

5-9(-13)

acute or subobtuse to rounded

serrulate and often strongly undulate in adult plants

always absent

compressed and shallowly grooved

\section{P. xjacobsii}

linear to linear-oblong

28-70

4-9

6-14

rounded to truncate or slightly retuse, not mucronate

entire (or rarely only very entire and plane minutely denticulate) and plane

0-12, present only in some leaves, very indistinct

(4-)10-34, always present, apparent under the microscope slightly compressed and terete shallowly grooved 
Although much attention has been paid to the identification of Potamogetonaceae hybrids in taxonomic research, our knowledge is confined to relatively few regions. In their recent worldwide revision of Potamogeton including Stuckenia, Wiegleb and Kaplan (1998) listed 50 confirmed hybrids, all from the Northern Hemisphere. The number of identified Potamogeton hybrids has increased to more than 80 (Z. Kaplan, unpubl.). A higher frequency and diversity of pondweed hybrids is associated with regions with specific ecological characteristics associated with postglacial dynamics (Kaplan 2007, Kaplan et al. 2009). These centres of hybridisation in Potamogeton and Stuckenia are mainly in the northern half of Europe, Japan, and eastern North America (Hagström 1916, Ogden 1943, Preston 1995, Wiegleb \& Kaplan 1998, Kaplan et al. 2009). Potamogeton hybrids have been, however, occasionally recorded from other regions and it can be assumed that they may also occur in areas where no targeted searches have been performed yet.

In this paper, we focus on the identity of a recently discovered Potamogeton plant in New South Wales (Hellquist 17201 \& Sainty), which showed morphology that was not consistent with the normal range of variation of Australian species, and did not fit the characteristics of any recognised taxon worldwide (Wiegleb \& Kaplan 1998). We employed a detailed investigation of morphology combined with molecular analyses to reveal the exact origins and identity of the Potamogeton plant.

\section{Material and Methods}

\section{Plant material}

The new plant, hereafter referred to as $P$. $\times j$ jacobsii, was collected during fieldwork in New South Wales, Australia. The site was a water-way running through a housing complex. The plant was growing in shallow water, not associated with any other Potamogeton taxon. Additional material used for comparison came from Australia, Europe, Asia and North America (P. crispus L.) and Australia and New Zealand (P. ochreatus Raoul). Plants of both P. crispus and P. ochreatus were cultivated in the Experimental Garden at the Institute of Botany, Průhonice, Czech Republic, and tested for phenotypic plasticity in order to better understand the origin of morphological variation (see also Kaplan 2002). In addition, herbarium specimens from around the world were investigated (for the complete list of herbaria see Kaplan 2008 and Kaplan 2010). Specimens included in the molecular analyses are summarised in Table 1. Most voucher specimens are held in the herbarium of the Institute of Botany, Průhonice (PRA) but vouchers for two samples collected by Michael Moody are lodged in the Western Australian Herbarium, Perth (PERTH).

\section{Morphological evaluation}

Morphological observations were made on recently collected herbarium material. Details of leaf morphology were studied using a stereomicroscope at a magnification of 20-75×. Abundant morphological data compiled for our previous studies were also considered in order to cover the morphological variation of the respective species as completely as possible. Only a brief description, mainly consisting of diagnostic characters, is given here for $P$. $\times$ jacobsii. The most important diagnostic characters are shown in microphotographs and summarised in Table 2 to facilitate comparison. Rare extremes were excluded from the quantitative data. 


\section{Identification of hybrids}

Potamogeton and Stuckenia hybrids are generally intermediate between the parental species (e.g., Hagström 1916, Preston 1995, Wiegleb \& Kaplan 1998). Although character expression in hybrids is generally unpredictable (Rieseberg \& Ellstrand 1993, Kaplan et al. 2009), several previous molecular studies (Hollingsworth et al. 1995; Kaplan et al. 2002; Fant \& Preston 2004; Kaplan \& Fehrer 2004, 2006; Kaplan \& Wolff 2004; Kaplan 2007) have demonstrated that for most Potamogeton and Stuckenia hybrids, either the parental species themselves or at least their respective species group can be reliably identified morphologically, as long as adequate expert inspection of a large set of key features is adopted. However, molecular proof of identification of Potamogeton hybrids is always advisable (Kaplan \& Fehrer 2007, 2009; Kaplan et al. 2009), particularly if a previously unknown hybrid combination is suspected.

Our previous studies have revealed a very low level of intra-individual polymorphism in the multicopy nuclear ribosomal ITS region for Potamogeton species as well as relatively little intraspecific variation while hybrids, the majority of which are sterile, maintained the ribotypes of their respective parents (Kaplan \& Fehrer 2007, 2009; Kaplan et al. 2009). These features provide an opportunity for the use of ITS sequencing as a very helpful tool in the detection of hybrids, which show additive patterns of their parents, i.e., superimposed peaks and insertions/deletions (indels) at diagnostic positions (Kaplan \& Fehrer 2007, Kaplan et al. 2009). We therefore performed direct ITS sequencing, complemented by cloning of the hybrid accession, in order to identify both parents. The maternal parent of the hybrid was revealed by sequencing of the rpl20-5'rps12 intergenic spacer region from chloroplast DNA.

\section{Molecular analyses}

DNA from the majority of samples was isolated from CTAB-preserved leaves (Štorchová et al. 2000) and used for both ITS and rpl20-5'rps12 sequencing. Isolated DNA of samples 2214 and 2215 was obtained from Michael Moody (Crawley, Australia). PCR amplifications and direct sequencing of the ITS and rpl20-5'rps12 regions were done as described in Kaplan \& Fehrer $(2004,2006)$. To investigate the possible hybrid origins of
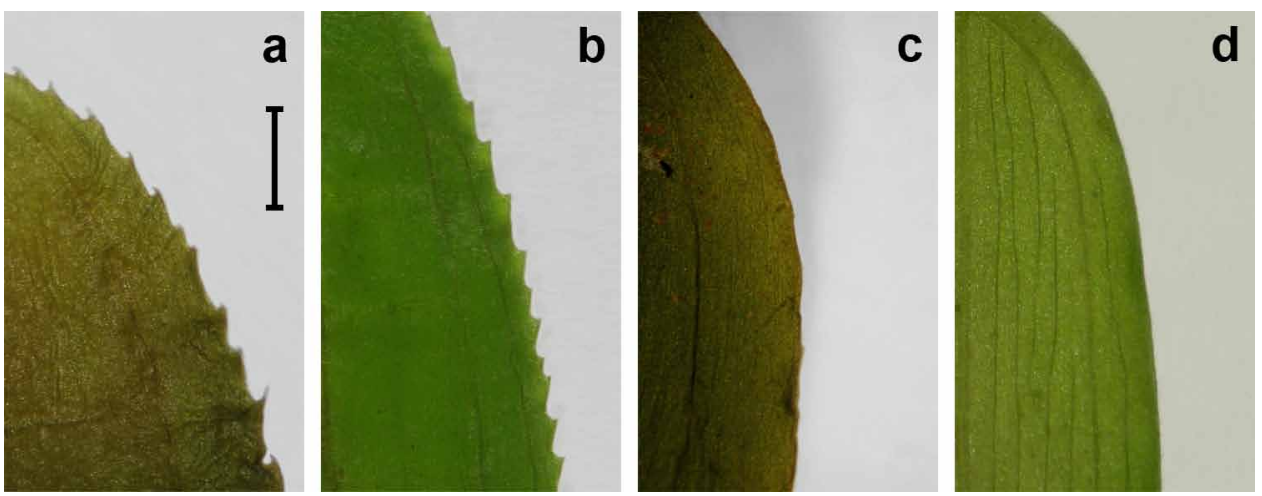

Fig. 1. Shape of leaf margin in Potamogeton. a, P. crispus (Kaplan 08-384); b, P. crispus (Kaplan 08-646); c, P. Xjacobsii (Hellquist 17201 \& Sainty); d, P. ochreatus (Kaplan 1071). Scale bar identical for all figures: $1 \mathrm{~mm}$. 
P. $\times$ jacobsii, the ITS region was also cloned using a pooled sample consisting of three separate PCR reactions to ensure representative amplification of the parental copies (Fehrer et al. 2009). Four clones were sequenced with the forward PCR primer and compared with each other and with direct sequencing to identify Taq DNA polymerase errors. GenBank accession numbers of all sequences are included in Table 1.

\section{Results}

\section{Morphological evaluation}

The new Potamogeton plant $(P . \times j a c o b s i i)$ resembles $P$. crispus in its general appearance, branching pattern and basic superficial features such as shape and colour of leaves, however, it differs in other characters of the leaves. Leaves of $P$. crispus have several characteristic features that are unlikely to be confused with those of any other species. In particular, they are serrulate (Figs $1 \mathrm{a} \& 1 \mathrm{~b}$ ), with teeth that are visible to the naked eye, and often strongly undulate along the margins. In contrast, the leaves of P. ×jacobsii are basically entire (Fig. 1c) and plane, as in P. ochreatus (Fig. 1d). The venation of $P$. crispus leaves usually consists of two veins on each side of the midrib,
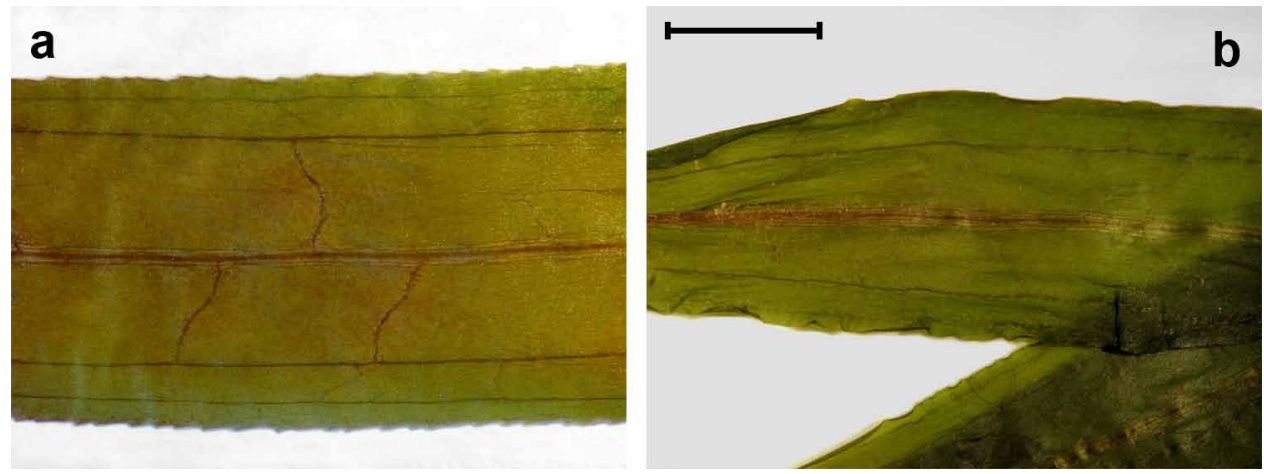

Fig. 2. Arrangement of vascular veins in Potamogeton leaves. a, P. crispus (Kaplan 07-41); b, P. ×jacobsii (Hellquist 17201 \& Sainty). Scale bar identical for both figures: $3 \mathrm{~mm}$.
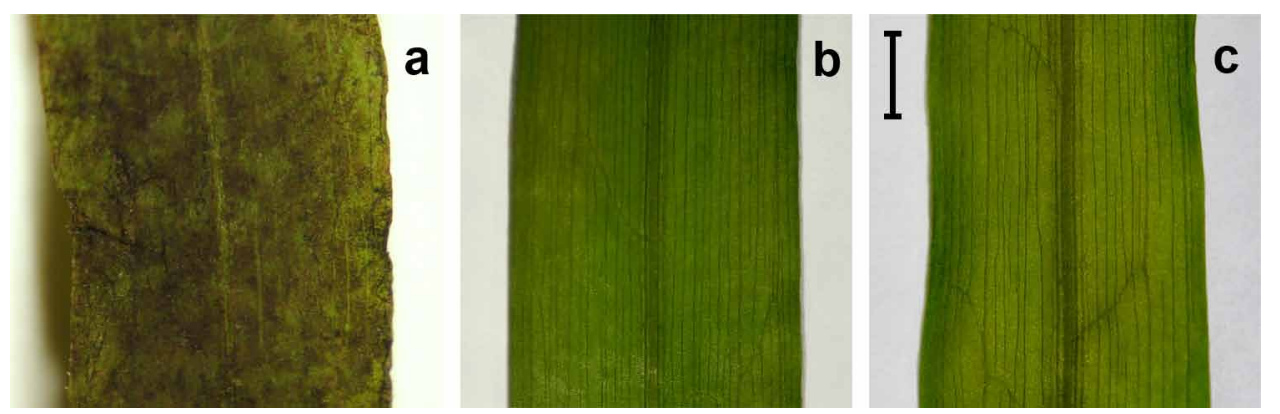

Fig. 3. Occurrence of sclerenchymatous strands in leaves of Potamogeton. a, P. $\times$ jacobsii (Hellquist 17201 \& Sainty); b \& c, P. ochreatus (Kaplan 1071). Scale bar identical for all figures: $1 \mathrm{~mm}$. 
with the outer pair of veins being faint and running close along the margins and the inner pair being more prominent and running longitudinally at approximately $1 / 2-2 / 3$ of the distance between the midrib and the margins (Fig. 2a). This venation pattern can be observed also in P. ×jacobsii (Fig. 2b), but some leaves contain also faint and irregular sclerenchymatous strands in addition to the vascular veins (Fig. 3a), which is clearly a character inherited from $P$. ochreatus, the only Australian species showing this structure (Fig. 3b). The leaves of $P$. $\times$ jacobsii are also similar to those of $P$. crispus in size, resembling narrow-leaved forms of this species (Figs $4 \mathrm{a} \& 4 \mathrm{~b}$ ), but in the hybrid they are often truncate or slightly retuse at the apex (Figs $4 \mathrm{c} \& 4 \mathrm{~d}$ ), and thus more similar to that of P. ochreatus (Figs 4e \& 4f). Hybrids of P. crispus often differ from their parents in the shape of the stem in cross-section (e.g., Hagström 1916, Preston 1995, Kaplan \& Fehrer 2004, Alix \& Scribailo 2006). The stem of P. crispus is compressed and shallowly grooved whereas that of $P$. ochreatus is terete. As far as it can be observed in the pressed specimen, the stem of the hybrid is also compressed, at least in some sections, but
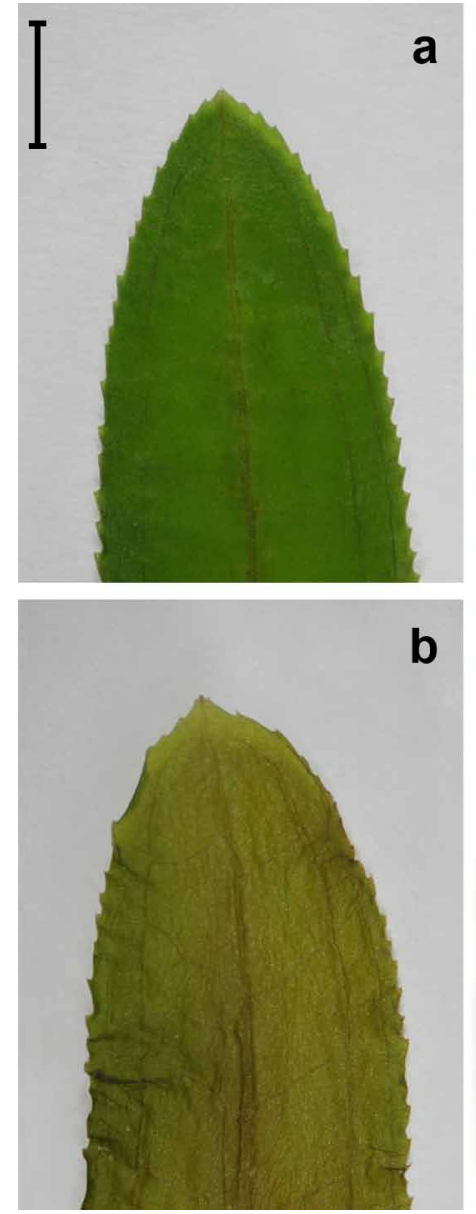
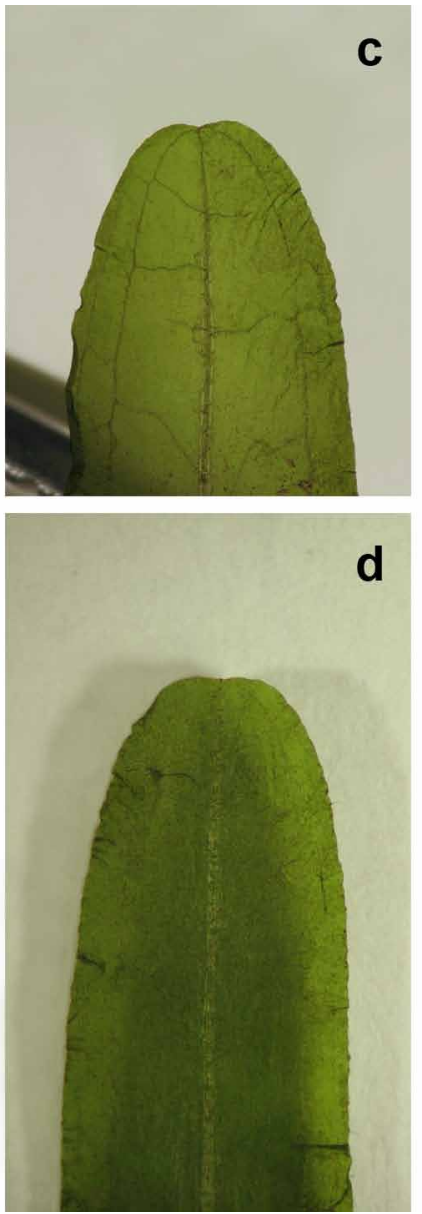
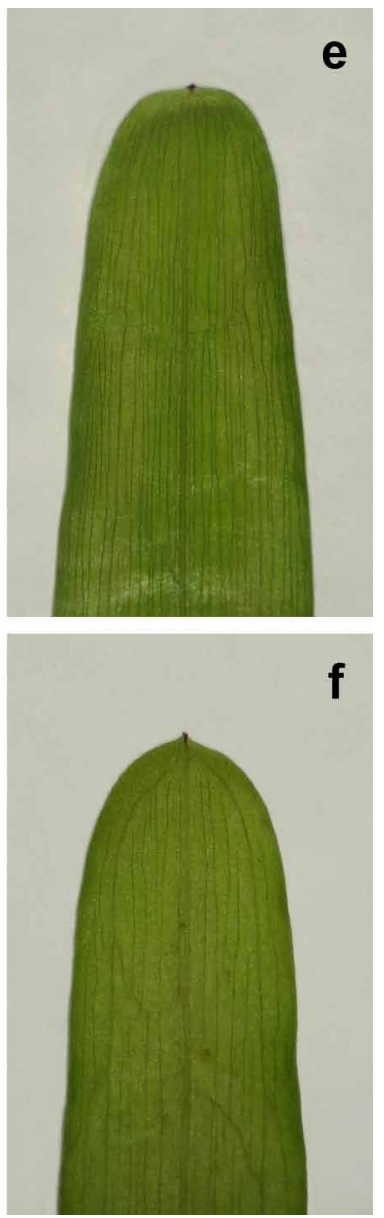

Fig. 4. Shape of leaf apex: a, P. crispus (Kaplan 08-646), b, P. crispus (Kaplan 08-384), c \& d, P. ×jacobsii (Hellquist 17201 \& Sainty), e \& f, P. ochreatus (Kaplan 1071). Scale bar identical for all figures: $2 \mathrm{~mm}$. 
clearly less markedly than is usual in $P$. crispus. These morphological observations clearly indicated that $P$. $\times$ jacobsii shows a combination of characters of $P$. crispus and $P$. ochreatus, most of them being intermediate between these species. The most important diagnostic characters of all three taxa are summarised in Table 2.

Both P. crispus and P. ochreatus are widespread throughout Australia but more common in temperate areas. All other species or species groups of Potamogeton documented from Australia can be easily excluded on morphological grounds as none have the characters that could explain the morphology shown by the putative hybrid. This is particularly true for all broad-leaved and mostly heterophyllous species with elliptical to ovate leaves, which differ by a suite of characters. These species constitute about two thirds of Australian Potamogeton species diversity. The only remaining species with linear submerged leaves, Potamogeton octandrus Poir., is also unlikely to be involved in the parentage of the investigated hybrid, particularly because the very narrow submerged leaves of the latter species lack the sclerenchymatous strands observed in P. ×jacobsii.

\section{Molecular evaluation}

Direct ITS sequencing of $P$. $\times$ jacobsii was mostly unreadable due to a large number of superimposed peaks and indel mutations, which is consistent with a hybrid origin. However, the readable 5'-end of the sequence contained 13 substitutions and one diagnostic indel suggesting a contribution of both P. crispus and P. ochreatus, when compared with our database of Potamogeton ITS sequences (Fehrer \& Kaplan, unpubl.). Sequencing of four clones of $P$. $\times$ jacobsii revealed that one (clone 11) was identical to $P$. ochreatus and three (clones $3,6 \& 15$ ) were identical or nearly identical to Australian (and Indian) P. crispus, which slightly differed from four European accessions of P. crispus (Table 3). The ITS sequences of $P$. crispus and P. ochreatus (730 bp in alignment) differ by 32 nucleotide substitutions, one $2 \mathrm{bp}$ - and four $1 \mathrm{bp}$-indels. Molecular data comparisons with other species also allowed us to exclude other putative parents: $P$. crispus is not only morphologically, but also genetically very distinct from all other Potamogeton species according to molecular phylogenies based on chloroplast or nuclear markers (Iida et al. 2004, Lindqvist et al. 2006, Zhang et al. 2008, Fehrer \& Kaplan, unpubl.). The species most closely related to $P$. crispus are $P$. maackianus A.Benn. and P. robbinsii Oakes (Lindqvist et al. 2006), which occur in eastern Asia and North America, respectively (Wiegleb \& Kaplan 1998) but not in the Southern Hemisphere. Their ITS sequences differ from P. crispus by more than 20 nucleotide substitutions and four indels (Fehrer \& Kaplan, unpubl.). Both species can also be excluded on the basis of their morphology. Potamogeton oxyphyllus Miq. is genetically most similar to P. ochreatus according to our ITS sequences (Fehrer \& Kaplan, unpubl.) but no phylogeny including both species has been published to date. Both species differ by four nucleotide substitutions and one indel. Potamogeton oxyphyllus can also be excluded on morphological grounds and because it occurs in eastern and southeastern Asia, but not in Australia (Wiegleb \& Kaplan 1998).

The chloroplast rpl20-5'rps12 sequences of P. crispus and P. ochreatus (totalling $794 \mathrm{bp}$ in alignment), did not show any intraspecific variation and differed by two nucleotide substitutions and one diagnostic $11 \mathrm{bp}$-indel (Table 4). While the overall variation is expectedly lower than that of the nuclear ITS region, these differences are sufficient to clearly distinguish between P. crispus and P. ochreatus; the Potamogeton hybrid sample had the P. crispus haplotype. 
ع99 | $1 \varangle \varangle \varangle \varangle \varangle \varangle$ 299 , । $\cup \cup \cup \cup \cup \cup$ $699 \cup \cup \quad 1 \quad 1 \quad 1 \quad 1 \quad 1 \quad 1$ $899 \cup \cup \varangle \varangle \varangle \varangle \varangle \varangle$ ऽ९9 $\varangle \varangle \cup \cup \cup \cup \cup \cup$ $\varepsilon 19 \cup \cup \vdash \vdash \vdash \vdash \vdash$ $909 \cup \cup \varangle \varangle \varangle \varangle \varangle \varangle$ $209 \vdash \vdash \cup \vdash \vdash \vdash \vdash$ ऽ $\vdash \vdash \cup \cup \cup \cup \cup \cup$ 76S $\cup \cup \vdash \vdash \vdash \vdash \vdash \vdash$

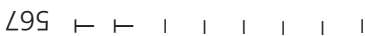
IES $\cup \cup \cup \cup \cup \cup \cup$ 8ZS $\cup \cup \vdash \vdash \vdash \vdash \vdash \vdash$ SZS $\vdash \vdash \vdash \longleftarrow \vdash \vdash \vdash \vdash$ EZS । । $\vdash \vdash \vdash \vdash \vdash \vdash$ †IS $\cup \cup \vdash \vdash \vdash \vdash \vdash$ EIS $\cup \cup \vdash \vdash \vdash \vdash \vdash$ $L L t \cup \cup \varangle \varangle \varangle \varangle \varangle \varangle$ $697 \vdash \vdash \vdash \vdash \vdash \vdash \varangle$ s9t $\cup \cup \vdash \vdash \vdash \vdash \vdash \vdash$ t9t $\vdash \vdash \cup \cup \cup \cup \cup \cup$ $197 \varangle \ll \vdash \vdash \vdash \vdash \vdash \vdash$ 6St $\cup \cup \vdash \vdash \vdash \vdash \vdash \vdash$ \&St $\cup \cup \vdash \vdash \vdash \vdash \vdash$ 8tt $\cup \cup \varangle \varangle \varangle \varangle \varangle \varangle$ عOt $\cup \cup \vdash \vdash \vdash \vdash \vdash$ $\nabla L Z \varangle \varangle \cup \vee \cup \cup \cup \cup$

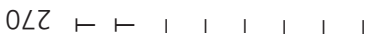

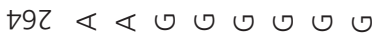
ISZ $\vdash \vdash \varangle \varangle \varangle \varangle \varangle \varangle$ OSZ $\cup \cup \vdash \vdash \vdash \vdash \vdash \vdash$ $6 \nabla 2 \varangle \varangle \vdash \vdash \vdash \vdash \vdash \vdash$ $\angle \nabla Z \cup \cup \vdash \vdash \vdash \vdash \vdash \vdash$ SદZ $\vdash \vdash \varangle \varangle \varangle \varangle \varangle \varangle$ ZZZ $৩ \cup \cup \cup \cup \cup \cup$ ZOZ $\cup \cup \varangle \varangle \varangle \varangle \varangle \varangle$ $861 \varangle \varangle \varangle \vdash \vdash \vdash \vdash$ Oع $\cup \cup \vdash \vdash \vdash \vdash \vdash$ $\angle 8 \varangle \varangle \vdash \vdash \vdash \vdash \vdash$ $98 \varangle \varangle \varangle \varangle \varangle \cup \cup \varangle$ SL $\vdash \vdash \varangle \varangle \varangle \varangle \varangle \varangle$ $0<\varangle \varangle \vdash \vdash \vdash \vdash \vdash$ Sऽ $\vdash \vdash \cup \cup \cup \cup \cup$
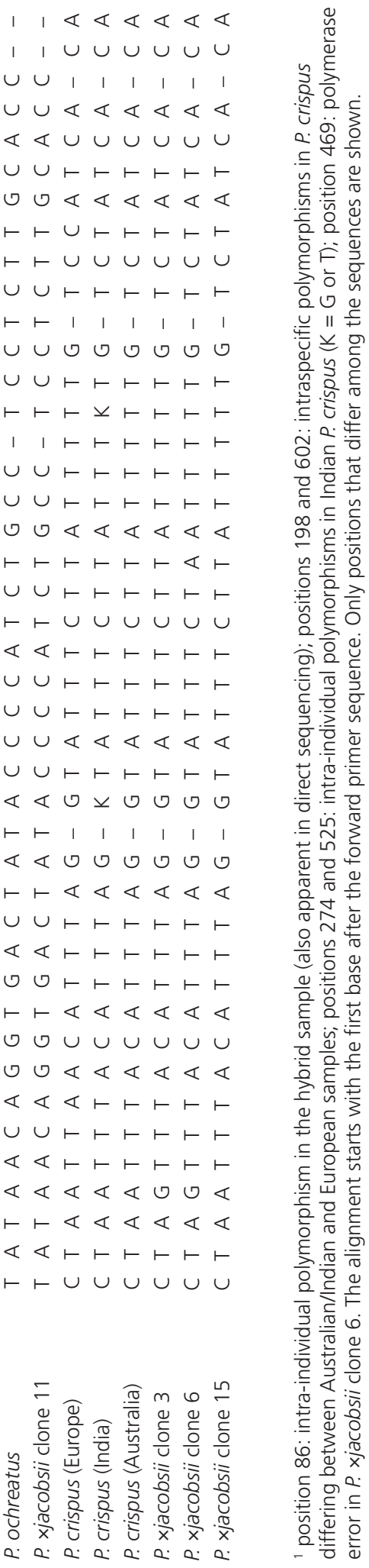
Table 4. Nucleotide sequence variation and haplotypes of Potamogeton crispus, $P$. ochreatus and their hybrid, P. xjacobsii in the $r p / 20-5$ 'rps 12 intergenic spacer region.

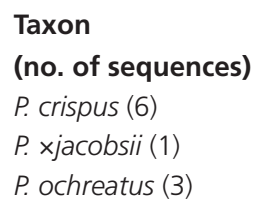

\begin{tabular}{lll}
\multicolumn{2}{l}{ Position in alignment } \\
67 & $249-259$ & 525 \\
T & - & $C$ \\
T & - & $C$ \\
G & AAAAAATAAAT & T
\end{tabular}

\section{Discussion}

The detailed morphological and molecular analyses led to the conclusion that $P$. $\times j a c o b s i i$ is a hybrid between P. crispus and P. ochreatus with the former as the maternal parent. Because our previous studies (Kaplan 2002, Kaplan \& Fehrer 2004, Kaplan et al. 2009) demonstrated that some extreme phenotypes of true species may mimic hybrids, and vice versa, the definitive and conclusive evidence came from molecular analyses. Because this hybrid combination has never been recorded before (see e.g., Graebner 1907, Hagström 1916, Wiegleb \& Kaplan 1998), it is here formally described and a new name is provided:

Potamogeton $\times$ jacobsii Z.Kaplan, Fehrer \& Hellq., nothosp. nova

(= P. crispus L. $\times$ P. ochreatus Raoul)

Diagnosis. Planta hybrida inter parentes intermedia; primo aspectu P. crispum revocans sed differt foliis angustioribus, margine integerrimis, apice truncatis vel retusis, et lineis sclerenchymatosis nerviformibus inter nervos foliorum primarios interjectis; a P. ochreato foliis latioribus, ordinatione nervis primariis diversa, lineis sclerenchymatosis multo paucioribus praecipue distinguitur.

Type. Australia: New South Wales: South Coast: Mt. Annan Cascades, Narellan, along shallow edge of lower pond in a series of man-made ponds along stream in housing development, $34^{\circ} 03.125^{\prime} \mathrm{S}, 150^{\circ} 45.237^{\prime} \mathrm{E}$, elevation $10 \mathrm{~m}, 17$ February 2009, C.B. Hellquist 17201 \& G. Sainty (holotype: PRA).

Description. Rhizome slender, creeping. Stem simple to sparingly branched, slender, slightly compressed and shallowly grooved. All leaves submerged, sessile, linear to linear-oblong, 28-70 mm long, 4-9 mm wide, 6-14 times as long as wide, bright green to dark green; base broadly cuneate; margin entire (rarely very minutely denticulate); apex rounded to truncate or slightly retuse (never mucronate); venation of 5 longitudinal vascular veins and either lacking sclerenchymatous strands or with up to 12 additional sclerenchymatous strands (only apparent in some leaves), with a narrow band of lacunae bordering midrib. Stipules axillary, convolute, short, decaying early. Generative organs not available.

Etymology. Named for the late Dr. Surrey W. L. Jacobs, an expert in Australian aquatic plants. 


\section{Final Note}

A combination of morphological and molecular approaches has recently led to several new discoveries concerning the diversity of Potamogeton hybrids. Character additivity of the ITS region has contributed to the discovery and/or exact identification of several entirely new hybrid combinations (Kaplan et al. 2009, Zalewska-Gałosz et al. 2010), detection of the occurrence of a long-overlooked hybrid (Zalewska-Gałosz et al. 2009) and even confirmed the existence of a triple hybrid in Potamogeton (Kaplan \& Fehrer 2007). It can be expected that more hybrids and other unrecorded components of Potamogeton and Stuckenia diversity will be discovered in the Southern Hemisphere. Australian field botanists interested in cooperation are encouraged to contact us. We offer our help in both morphological and molecular checking of the identity of unclear Potamogeton samples.

\section{Acknowledgments}

The authors thank Michael Moody (Crawley, Australia), Donald H. Les (Storrs, U.S.A.), Deborah Hofstra (Hamilton, New Zealand), Lenz Meierott (Gerbrunn, Germany) and Aijaz H. Ganie (Srinagar, India) for collecting additional material of the parental species for comparison, Geoff Sainty (Sydney, Australia) for his help with the fieldwork and A. Yadollahi (Průhonice, Czech Republic) for the molecular labwork. The research was supported by grant no. 206/09/0291 from the Czech Science Foundation, and the long-term institutional research plan no. AV0Z60050516 from the Academy of Sciences of the Czech Republic.

\section{References}

Alix MS \& Scribailo RW (2006) First report of Potamogeton $\times$ undulatus (P. crispus $\times$ P. praelongus, Potamogetonaceae) in North America, with notes on morphology and stem anatomy. Rhodora 108: 329-346.

Du Z-Y, Yang C-F, Chen J-M \& Guo Y-H (2009) Nuclear and chloroplast DNA sequences data support the origin of Potamogeton intortusifolius J.B. He in China as a hybrid between P. perfoliatus Linn. and P. wrightii Morong. Aquatic Botany 91: 47-50.

Fant JB \& Preston CD (2004) Genetic structure and morphological variation of British populations of the hybrid Potamogeton $\times$ salicifolius. Botanical Journal of the Linnean Society 144: 99-111.

Fant JB, Preston CD \& Barrett JA (2001a) Isozyme evidence for the origin of Potamogeton $\times$ sudermanicus as a hybrid between P. acutifolius and P. berchtoldii. Aquatic Botany 71: 199-208.

Fant JB, Preston CD \& Barrett JA (2001b) Isozyme evidence of the parental origin and possible fertility of the hybrid Potamogeton $\times$ fluitans Roth. Plant Systematics and Evolution 229: 45-57.

Fant JB, Kamau EA \& Preston CD (2003) Chloroplast evidence for the multiple origins of the hybrid Potamogeton $\times$ sudermanicus Hagstr. Aquatic Botany 75: 351-356.

Fehrer J, Krak K \& Chrtek J Jr (2009) Intra-individual polymorphism in diploid and apomictic polyploid hawkweeds (Hieracium, Lactuceae, Asteraceae): disentangling phylogenetic signal, reticulation, and noise. BMC Evolutionary Biology 9: 239.

Fischer G (1904) Beitrag zur Kenntnis der bayerischen Potamogetoneen IV. Mitteilungen der Bayerischen Botanischen Gesellschaft 1: 356-366 \& 375-388. 
Fischer G (1905) Beitrag zur Kenntnis der bayerischen Potamogetoneen V. Mitteilungen der Bayerischen Botanischen Gesellschaft 1: 471-475.

Fischer G (1907) Die bayerischen Potamogetonen und Zannichellien. Berichte der Bayerischen Botanischen Gesellschaft 11:20-162.

Graebner P (1907) Potamogeton. Pp. 39-142 \& 161-162 in Engler A (ed.) Das Pflanzenreich, Regni vegetabilis conspectus, vol. 31 (IV.11). (Wilhelm Engelmann: Berlin)

Hagström JO (1916) Critical researches on the Potamogetons. Kungliga Svenska Vetenskapsakademiens Handlingar 55(5): 1-281.

Hollingsworth PM, Preston CD \& Gornall RJ (1995) Isozyme evidence for hybridization between Potamogeton natans and P. nodosus (Potamogetonaceae) in Britain. Botanical Journal of the Linnean Society 117: 59-69.

Hollingsworth PM, Preston CD \& Gornall RJ (1996) Isozyme evidence for the parentage and multiple origins of Potamogeton $\times$ suecicus (P. pectinatus $\times$ P. filiformis, Potamogetonaceae). Plant Systematics and Evolution 202: 219-232.

Iida S \& Kadono Y (2002) Genetic diversity and origin of Potamogeton anguillanus (Potamogetonaceae) in Lake Biwa, Japan. Journal of Plant Research 115: 11-16.

Iida S, Kosuge K \& Kadono Y (2004) Molecular phylogeny of Japanese Potamogeton species in light of noncoding chloroplast sequences. Aquatic Botany 80: 115-127.

Ito Y, Tanaka N \& Uehara K (2007): Inferring the origin of Potamogeton Xinbaensis (Potamogetonaceae) using nuclear and chloroplast DNA sequences. Journal of Japanese Botany 82: 20-28.

Kaplan Z (2001) Potamogeton $\times$ fluitans $(P$. natans $\times$ P. lucens) in the Czech Republic. I. Morphology and anatomy. Preslia 73: 333-340.

Kaplan Z (2002) Phenotypic plasticity in Potamogeton (Potamogetonaceae). Folia Geobotanica 37: $141-170$.

Kaplan Z (2005a) Neotypification of Potamogeton $\times$ fluitans Roth and the distribution of this hybrid. Taxon 54: 822-826.

Kaplan Z (2005b) Potamogeton schweinfurthii A. Benn., a new species for Europe. Preslia 77: 419-431.

Kaplan Z (2007) First record of Potamogeton $\times$ salicifolius for Italy, with isozyme evidence for plants collected in Italy and Sweden. Plant Biosystems 141: 344-351.

Kaplan Z (2008) A taxonomic revision of Stuckenia (Potamogetonaceae) in Asia, with notes on the diversity and variation of the genus on a worldwide scale. Folia Geobotanica 43: 159-234.

Kaplan Z. (2010) Hybridization of Potamogeton species in the Czech Republic: diversity, distribution, temporal trends and habitat preferences. Preslia 82: 261-287.

Kaplan Z \& Fehrer J (2004) Evidence for the hybrid origin of Potamogeton $\times$ cooperi (Potamogetonaceae): traditional morphology-based taxonomy and molecular techniques in concert. Folia Geobotanica 39: 431-453.

Kaplan Z \& Fehrer J (2006) Comparison of natural and artificial hybridization in Potamogeton. Preslia 78: 303-316.

Kaplan Z \& Fehrer J (2007) Molecular evidence for a natural primary triple hybrid in plants revealed from direct sequencing. Annals of Botany 99: 1213-1222.

Kaplan Z \& Fehrer J (2009) An orphaned clone of Potamogeton $\times$ schreberi in the Czech Republic. Preslia 81: 387-397.

Kaplan Z \& Symoens JJ (2004) Proposal to conserve the name Potamogeton schweinfurthii A. Benn. (Potamogetonaceae) with a conserved type. Taxon 53: 837-838.

Kaplan Z \& Symoens JJ (2005) Taxonomy, distribution and nomenclature of three confused broad-leaved Potamogeton species occurring in Africa and on surrounding islands. Botanical Journal of the Linnean Society 148: 329-357.

Kaplan Z \& Wolff P (2004) A morphological, anatomical and isozyme study of Potamogeton $\times$ schreberi: confirmation of its recent occurrence in Germany and first documented record in France. Preslia 76: 141-161. 
Kaplan Z, Plačková I \& Štěpánek J (2002) Potamogeton $\times$ fluitans (P. natans $\times$ P. lucens) in the Czech Republic. II. Isozyme analysis. Preslia 74: 187-195.

Kaplan Z, Fehrer J \& Hellquist CB (2009) New hybrid combinations revealed by molecular analysis: The unknown side of North American pondweed diversity (Potamogeton). Systematic Botany 34: 625-642.

King RA, Gornall RJ, Preston CD \& Croft JM (2001) Molecular confirmation of Potamogeton $\times$ bottnicus (P. pectinatus $\times$ P. vaginatus, Potamogetonaceae) in Britain. Botanical Journal of the Linnean Society 135: 67-70.

Lindqvist C, De Laet J, Haynes RR, Aagesen L, Keener BR \& Albert VA (2006) Molecular phylogenetics of an aquatic plant lineage, Potamogetonaceae. Cladistics 22: 568-588.

Ogden EC (1943) The broad-leaved species of Potamogeton of North America north of Mexico. Rhodora 45: 57-105, 119-163 \& 171-214.

Preston CD (1995) Pondweeds of Great Britain and Ireland. (Botanical Society of the British Isles: London)

Preston CD, Hollingsworth PM \& Gornall RJ (1998) Potamogeton pectinatus L. $\times$ P. vaginatus Turcz. (P. $\times$ bottnicus Hagstr.), a newly identified hybrid in the British Isles. Watsonia 22: 69-82.

Raunkiær C (1896) De danske Blomsterplanters Naturhistorie. I. Enkimbladede [Natural history of Danish flowering plants. I. Monocotyledons]. (Gyldendalske Boghandels Forlag: Kjøbenhavn)

Raunkiær C (1903) Anatomical Potamogeton-studies and Potamogeton fluitans. Botanisk Tidsskrift 25: 253-280.

Rieseberg LH \& Ellstrand NC (1993) What can molecular and morphological markers tell us about plant hybridization. Critical Reviews in Plant Sciences 12: 213-241.

Symoens JJ, van de Velden J \& Büscher P (1979) Contribution a l'étude de la taxonomie et de la distribution de Potamogeton nodosus Poir. et $P$. thunbergii Cham. et Schlechtend. en Afrique. Bulletin de la Société Royale de Botanique de Belgique 112: 79-95.

Štorchová H, Hrdličková R, Chrtek J, Tetera M, Fitze D \& Fehrer J (2000) An improved method of DNA isolation from plants collected in the field and conserved in saturated $\mathrm{NaCl} / \mathrm{CTAB}$ solution. Taxon 49: 79-84.

Wang QD, Zhang T \& Wang JB (2007) Phylogenetic relationships and hybrid origin of Potamogeton species (Potamogetonaceae) distributed in China: Insights from the nuclear ribosomal internal transcribed spacer sequence (ITS). Plant Systematics and Evolution 267: 65-78.

Wiegleb G (1990a) A redescription of Potamogeton wrightii (Potamogetonaceae). Plant Systematics and Evolution 170: 53-70.

Wiegleb G (1990b) The importance of stem anatomical characters for the systematics of the genus Potamogeton L. Flora 184: 197-208.

Wiegleb G \& Kaplan Z (1998) An account of the species of Potamogeton L. (Potamogetonaceae). Folia Geobotanica 33: 241-316.

Wiegleb G, van de Weyer K, Bolbrinker P \& Wolff P (2008) Potamogeton-Hybriden in Deutschland. Feddes Repertorium 119: 433-448.

Zalewska-Gałosz J, Ronikier M \& Kaplan Z (2009) The first European record of Potamogeton Xsubobtusus identified using ITS and cpDNA sequence data. Preslia 81:281-292.

Zalewska-Gałosz J, Ronikier M \& Kaplan Z (2010) Discovery of a new, recurrently formed Potamogeton hybrid in Europe and Africa: molecular evidence and morphological comparison of different clones. Taxon 59 (in press).

Zhang T, Wang Q, Li W, Cheng Y \& Wang J (2008) Analysis of phylogenetic relationships of Potamogeton species in China based on chloroplast trnT-trnF sequences. Aquatic Botany 89: 34-42. 